\title{
Carnalidade, alteridade e liberdade: a humanização de Deus e as implicações antropológico-pastorais das cristologias de José María Castillo e Joseph Moingt
}

\author{
Orientadora: Lúcia Pedrosa de Pádua \\ Doutorando: Roberto Nentwig \\ Área de Concentração: Teologia Sistemático-Pastoral \\ Linha de Pesquisa: Religião e Modernidade \\ Projeto de Pesquisa: A teologia da criação-salvação mediante Jesus Cristo \\ em diálogo com a cultura e as ciências
}

O desafio da comunicação da fé cristã, depois do surgimento da modernidade, abre-nos a oportunidade da ressignificação dos conteúdos da fé, que se realiza pela superação da linguagem dogmática e pela proposição de uma teologia com linguagem mais afinada com as fontes do Evangelho. Entre tantas propostas neste intento, este trabalho optou por construir um caminho de ressignificação a partir da humanização de Deus, ou seja, seguindo uma cristologia ascendente: considera a concretude história de Jesus, levando a sério a radicalidade da quenosis do Verbo. A pesquisa desenvolve-se dentro de uma tríade que caracteriza uma antropologia de base, ou seja, o que é imprescindível na existência humana: carnalidade, alteridade e liberdade. Tendo bem presente a cristologia da humanização de Deus e pautado pelos três elementos enunciados, este trabalho aborda a cristologia de José María Castillo e de Joseph Moingt. O primeiro teólogo, em sintonia com a teologia latino-americana, traz uma reflexão crítica diante de algumas posturas eclesiais e teológicas que produziram uma apresentação de Jesus distante de sua história, bem como do discipulado, verdadeira exigência da fé. O segundo, por sua vez, também ressalta a humanidade de Jesus e a importância das fontes bíblicas, tendo como diferencial o diálogo com as ciências humanas, com filosofia da intersubjetividade e com uma grande gama de teólogos expoentes. Destas duas cristologias emergem aproximações e complementariedades que nos possibilitam deduzir uma caracterização cristológica. Desta cristologia, construímos, como implicação, uma antropologia pautada nos mesmos três elementos (carnalidade, alteridade e liberdade), além de deslocamentos pastorais importantes para a atualidade.

Palavras-chave: Humanização de Deus. Carnalidade. Alteridade. 